\title{
US panel backs LHC, but seeks extra funds
}

Washington. High-energy physics needs an extra $\$ 150$ million over the three years 1996 to 1998 both to ensure a healthy US domestic programme and to start collaboration with Europe on the proposed Large Hadron Collider (LHC), according to a key advisory panel to the Clinton administration.

But the panel, chaired by Sidney Drell of the Stanford Linear Accelerator Center (SLAC) in California, said in a report published in Washington on Monday that if the extra money cannot be found, the government should axe unspecified elements of the domestic programme in order to proceed with collaboration on the LHC.

The Drell panel - a sub-group of the High Energy Physics Advisory Panel (HEPAP) - was set up by Hazel O'Leary, the Secretary of Energy, to provide advice on how her department's $\$ 650$ million-ayear high-energy physics programme should proceed after last year's abandonment of the Superconducting Super Collider (SSC).

Both White House officials and members of Congress have been eagerly awaiting its report before taking up positions on the future of the field.

The panel said that the extra $\$ 150$ million is needed to tide the programme over a period in which large construction programmes at Fermilab, Illinois and at SLAC will strain resources. After that, it added, the budget could return to $\$ 650$ million a year (adjusted for inflation).

This would provide sufficient funds both to support the domestic programme and to provide a contribution to the LHC, which would total $\$ 400$ million by 2003 . Drell says this would enable a "lean" US involvement in LHC. "It's not what some proponents would have wished for, but we're trying to be practical," he says.

Under the plan, little money would go to LHC until 1998. But the panel calls for an early and unequivocal statement from the US government endorsing participation in the LHC, to which European governments are expected to commit themselves next month.

Drell says that international collaboration will not work without an endorsement from President Clinton himself, and that it is needed to show young scientists that the government is committed to the field. The panel said that this endorsement should be made even if the extra $\$ 150$ million is not forthcoming from Congress, and the budget remains flat.

Drell warned HEPAP on Monday that if that happened "you guys are going to have to sit down and decide what to kill" from the domestic programme. HEPAP members say privately that possible candidates for extinction would include operations at Brookhaven, New York and at SLAC.

The Drell report has received strong backing from HEPAP itself, and is now being

forwarded to O'Leary, while various panel members are urging the wider physics community to unite behind it.

With real cuts of $\$ 135$ million over the past three years in high energy physics funding, Drell says that "we have a programme in trouble." The $\$ 150$ million, he says, "is one-and-a-half per cent of the cost of the SSC and would get us through the present crisis so that we could build for the future."

Drell also voiced concern about the extra costs which Department of Energy regulations place on the high energy physics programme. One comparison between the National Science Foundation and the department indicated that the latter was paying 7 per cent extra to meet its own regulations.

"Someone has to look at these things because there is a lot of money going out the door," says Drell. Seven per cent of the programme, he points out, is virtually equivalent to the extra $\$ 50$ million a year which his report calls for.

In her first reaction to the report, Martha Krebs, the head of energy research at the Department of Energy, said she understood why it had asked for the extra $\$ 150$ million. But she added - perhaps ominously — that

\section{Tensions surface in Pasteur dispute}

Paris. The Institut Pasteur in Paris is investigating the operation of its laboratory of cellular immunology, some two years after an earlier enquiry found evidence of scientific misconduct by a postdoctoral researcher in the laboratory.

The institute says it wants to know more about the "background" to the misconduct, although it insists that the enquiry concerns only the quality of work in the laboratory, and not the misconduct incident.

But the director of the laboratory, Jacques Thèze, claims that pressure for the second enquiry has come from adversaries keen to exploit what he describes as a minor incident in order to discredit him. In particular, some say that Thèze's efforts to reform the Institut Pasteur in Lyons, which he headed between 1990 and 1992, have made him enemies.

The misconduct affair involved a postdoctoral researcher, Dragana Jankovic, who, according to Pasteur documents, fabricated results from gels in a paper on expression of viral oncogenes submitted to the Proceedings of the National Academy of Sciences in 1992.

The paper was withdrawn in October 1992 by Thèze and Moshe Yaniv — a coauthor and head of the laboratory of viral oncogenes. Yaniv says their suspicions were aroused when a colleague of Jankovic's, Angelita Rebello, became reluctant to sign "they've also taken a realistic approach to what the field should do if they don't get it."

The report was welcomed by Congressional supporters of physics. The House science subcommittee chaired by Rick Boucher (Democrat, Virginia) held a hearing on Monday at which Boucher and others - including SSC's chief executioner, Sherwood Boehlert (Republican, New York) expressed their support for both the LHC and the extra $\$ 150$ million.

But political reality remains more fraught than the public reception of the Drell report suggests. A tight budget climate makes it highly unlikely that Congress will restore to high-energy physics money which it has only recently cut. If the budget stays level, Congress will be loathe to implement any HEPAP recommendation to run down facilities in California or New York State in order to fund the LHC in Switzerland.

It is in anticipation of such problems that Drell is stressing the need for a clear lead from President Clinton. But so far there has been no sign from the president's Office of Science and Technology Policy that such a lead will be forthcoming.

Colin Macilwain

the paper, and that she subsequently told them what Jankovic had done.

When Maxime Schwartz, the director of the Institut Pasteur, heard of the allegations, he promptly set up an enquiry. Schwartz says that Jankovic subsequently confessed and "resigned" (Jankovic could not be traced for comment). He also says that the first enquiry found no evidence that Thèze knew of or suspected the misconduct beforehand.

Nevertheless, according to Schwartz, the second enquiry was set up to address the concerns of some researchers at the Pasteur that aspects of the operation of Thèze's laboratory might have been conducive to Jankovic's misconduct.

But "no smoke without fire" has been one reaction to the second investigation into Thèze's laboratory. Moreover, some argue that the institute must accept much of the responsibility for creating this climate of suspicion.

Furthermore, Pasteur documents also show that the first enquiry found that Antonio Coutinho, the head of the immunology department, and Philippe Kourilsky, his deputy and a scientific director of the Lyons-based company Laboratoires Mérieux, both knew of the allegations of misconduct in June 1992, but waited until October before telling Schwartz.

This finding has been kept confidential, and has created further suspicion, this 